\title{
SURGICAL SITE INFECTIONS IN PATIENTS AFTER POSTERIOR LUMBAR SPINE FUSION
}

\author{
INFECÇÕES NO LOCAL CIRÚRGICO EM PACIENTES APÓS A FUSÃO POSTERIOR \\ $D A L O M B A R$
}

\author{
INFECCIONES DEL SITIO QUIRÚRGICO EN PACIENTES DESPUÉS DE LA FUSIÓN \\ LUMBAR POSTERIOR
}

\author{
Vadim Anatol'evich Byvaltsev¹, Ivan Andreevich Stepanov11, Vladislav Eduardovich Borisov¹, Medetbek Djumabekovich Abakirov² \\ 1. Irkutsk State Medical University, Irkutsk, Russia. \\ 2. People's Friendship University of Russia, Moscow, Russia
}

\begin{abstract}
Objective: Infectious complications are the most common cause of unsatisfactory results of surgical treatment and prolongation of hospitalization in patients following spinal surgery. The purpose - to assess the microbiological characteristics of SSI in patients after posterior lumbar fusion for degenerative disease, and to determine the relationship between these characteristics and surgical features of SSIs. Methods: A single-center retrospective non-randomized cohort study was performed, 1563 patients aged 37 to 59 years were included in the study. Microbiological characteristics were analyzed, and their interrelations with the surgical features of all cases of SSls were determined. Results: The incidence of SSIs was 2.67\% (41). Monomicrobial SSIs were detected in 46.3\% (19) patients, polymicrobial in $36.5 \%$ (15) cases, and negative results of inoculation in $17.07 \%$ (7) patients. The most frequent pathogens of SSIs in the study group were S. aureus and S. epidermidis - 37.9\% (33) and 24.1\% (21), respectively. The period of development of symptoms of SSIs in patients

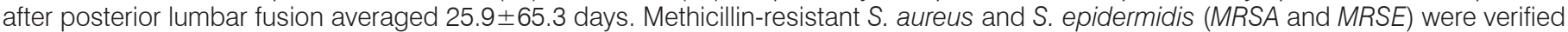
in $24.1 \%$ (21) cases. Conclusions: Assessment of microbiological characteristics should be carried out in all diagnosed cases of SSIs in patients after spine surgical interventions, as these are closely linked to the surgical features of the infectious process. Also, the treatment tactics for this group of patients should be determined by a medical team working in conjunction. Level of evidence IV; Descriptive study.
\end{abstract}

Keywords: Surgical Wound Infection; Spine; Surgical Procedures, Operative; Microbiology.

\section{RESUMO}

Objetivos: As complicações infecciosas são a causa mais comum de resultados insatisfatórios no tratamento cirúrgico e de prolongamento da hospitalização em pacientes após cirurgia da coluna vertebral. O objetivo - avaliar as características microbiológicas do SSI em pacientes após a fusão lombar posterior para sua doença degenerativa e determinar a relação entre essas características e as características cirúrgicas de SSIs. Métodos: Um estudo de coorte retrospectivo não aleatorizado de um centro foi realizado, 1563 pacientes com idade entre 37 e 59 anos foram incluídos no estudo. As características microbiológicas são analisadas e sua interação com as características cirúrgicas de todos os casos de SSIs é determinada. Resultados: A incidência de SSIs foi de 2,67\% (41). Os SSI monomicrobianos foram detectados em 46,3\% (19) pacientes, polimicrobianos - em 36,5\% (15) casos e resultados negativos de inoculação - em 17,07\% (7) pacientes. Os agentes patogénicos mais frequentes das SSI no grupo de estudo foram S. aureus e S.epidermidis - 37,9\% (33) e 24,1\% (21), respectivamente. Conclusões: A avaliação das características microbiológicas deve ser realizada em todos os casos diagnosticados de SSI em pacientes após intervenções cirúrgicas da coluna vertebral em conexão inextricável com as características cirúrgicas do processo infeccioso, e as táticas de tratamento deste grupo de pacientes devem ser determinadas estritamente colegialmente. Nível de evidência IV; Estudo descriptivo.

Descritores: Infecção da ferida cirúrgica; Coluna vertebral; Procedimentos Cirúrgicos; Microbiologia.

\section{RESUMEN}

Objetivo: Las complicaciones infecciosas son la causa más común de resultados insatisfactorios del tratamiento quirúrgico y la prolongación de la hospitalización en pacientes después de la cirugía espinal. El objetivo es evaluar las características microbiológicas de la ISQ en pacientes después de una fusión lumbar posterior por su enfermedad degenerativa, y determinar la relación entre estas características y las características quirúrgicas de las ISQ. Métodos: Se realizó un estudio de cohorte retrospectivo no aleatorizado de un centro, 1563 pacientes de 37 a 59 años de edad fueron incluidos en el estudio. Se analizó las características microbiológicas y se determinó su interrelación con las características quirúrgicas de todos los casos de ISQ. Resultados: La incidencia de ISQ fue del 2,67\% (41). Se detectaron ISQ monomicrobianas en 46,3\% (19) pacientes, polimicrobianas, en 36,5\% (15) casos y resultados negativos de inoculación, en 17,07\% (7) pacientes. Los patógenos más frecuentes de las ISQ en el grupo de estudio fueron S. aureus y S. epidermidis: 37,9\% (33) y 24,1\% (21), respectivamente. El período promedió de desarrollo de síntomas de ISQ en pacientes después de la fusión lumbar posterior fue de 25,9 9 65, 3 días. Conclusiones: La evaluación de las características microbiológicas debe llevarse a cabo en todos los casos diagnosticados de ISQ en pacientes después de intervenciones quirúrgicas espinales en conexión inextricable con las características quirúrgicas del proceso infeccioso. Además de eso, las tácticas de tratamiento de este grupo de pacientes deben determinarse estrictamente de forma colegiada. Nivel de evidencia IV; Estudio descriptivo.

Descriptores: Infección de la herida quirúrgica; Columna vertebral; Procedimientos quirúrgicos; Microbiología. 


\section{INTRODUCTION}

It is known that infectious complications are the most common cause of unsatisfactory results of surgical treatment and prolongation of hospitalization in patients following spinal surgery. ${ }^{1,2}$ According to the National Register of Infections, surgical site infections (SSIs) are the third most frequently registered nosocomial infection, accounting for $14-16 \%$ of cases of infection among hospitalized patients. ${ }^{3}$ Often, SSIs require complex treatment to cure the inflammatory process, up to the time of repeated audit operations. Due to their high incidence rate, SSIs are a significant economic «burden» for practical health care; the costs associated with SSIs in the US and Europe range from $\$ 15,800$ to $\$ 43,900$ for each newly identified case of SSI. ${ }^{4,5}$ In addition, SSIs are a direct factor affecting one of the most important indicators in the work of a health care institution and practical health care in general, which is the quality of specialized medical care. ${ }^{6}$

Some small randomized clinical and retrospective studies confirm the effectiveness of individual antimicrobial drugs in the prevention of SSIs in patients after spinal surgery. ${ }^{7-10}$ Nevertheless, so far, in many clinical recommendations for the prevention of SSIs there is no common opinion in regard to the selection of certain groups of antibacterial agents in this group of patients. When choosing antibacterial drugs, it is necessary to take into account their broad activity in vitro with respect to the most probable pathogens characteristic for this species and the localization of SSIs. ${ }^{11,12}$ When searching for literature sources in the Pubmed, Medline and E- library databases, we found only single reports devoted to the study of the microbiological characteristics of SSIs in patients after surgical operations on the spine. These studies include a small number of respondents and do not take into account the relationship between microbiological characteristics and surgical features of SSIs. ${ }^{13-16}$

A modern understanding of the problem of SSIs in conditions of growing resistance of microorganisms to antibacterial drugs includes an assessment of the microbiological characteristics of each $\mathrm{SICl}$ case in indissoluble connection with the surgical features of this type of complications. All this allows us to choose a rational tactic for antimicrobial therapy, and to develop effective antibiotic prophylaxis for SSIs, while minimizing adverse drug reactions.

The purpose of this study was to evaluate the characteristics of SSIs in patients following posterior lumbar fusion, and to determine the relationship between these characteristics and the surgical features of SSIs.

\section{METHODS}

A single-center retrospective non-randomized cohort study was performed.

The study included all cases of SSIs in patients after posterior lumbar fusion.

The criteria for exclusion from the study were: (1) age over 60 years, (2) osteoporosis, (3) suffered spine trauma, (4) decompensated diabetes mellitus, (5) chronic heart disease, (6) renal failure, and (7) secondary immunodeficiency states.

The study was performed at the Neurosurgical Center of Road Clinical Hospital, St. Irkutsk-Passenger (Irkutsk, Russia).

The study was conducted between March 2012 and November 2017.

Each case of SSIs was confirmed by the medical team working in conjunction, consisting of a neurosurgeon, a general surgeon, and an infectious disease specialist, taking into account clinical and laboratory data, and classified according to the recommendations of the National Nosocomial Infection Surveillance (NNIS). ${ }^{17}$

Surgical features of SSIs in the study group included: (1) the duration of the development of SSI symptoms from the time of surgery, (2) the prevalence of SSI in the patient groups after the first operation and after repeated operations on the lumbosacral spine, (3) as well as the frequency of occurrence of this complication, depending on the level of the operated vertebral-motor segment.

Bacteriological study of the separated postoperative wounds was carried out according to the methodological recommendations of the sanitary-epidemiological regime. The material for the study was carefully collected using a sterile Pasteur pipette with a rubber pear, and placed in a sterile tube.

The sowing was performed on universal dense nutrient media by the Lincei method. To isolate staphylococci, we sowed directly on a Petri dish with yellow-salt agar medium (Chistovich's medium). In addition, as a storage medium, we used broth with $6.5 \%$ sodium chloride, a broth with $1 \%$ glucose, poured into $0.5 \mathrm{ml}$ tubes, in which $0.2-0.3 \mathrm{ml}$ of flushing liquid was inoculated. The seeded tubes were incubated at $37^{\circ} \mathrm{C}$ for $20-24$ hours, after which they were seeded on Chistovich's medium. To identify the bacteria of the group of $E$. coli, seeding on the enrichment medium was performed, for which a tampon was immersed in $10-20 \%$ bile broth or Kessler's medium. A day later, the incubation at $37^{\circ} \mathrm{C}$ was performed by transferring to Endo medium. The identification of strains was carried out taking into account their morphological and cultural characteristics. Antisensitivity was determined by the disk method. For each identification of microbial association during the bacteriological examination, the microorganisms detected were individually recorded.

The study was approved by the ethics committee of the Irkutsk State Medical University (No. 12 of 08.02.2016). The study was conducted in accordance with the principles of good clinical practice and the Helsinki Declaration. ${ }^{18}$ Before the study, patients provided written informed consent.

Statistical processing of data was carried out using Microsoft Excel 2010 software. The data obtained are presented in the form $\mathrm{M} \pm \mathrm{SD}$ ( $\mathrm{M}$ is the mean value, $\mathrm{SD}$ is the standard deviation). The relationship between the microbiological and surgical characteristics of SSI was estimated using the $\chi^{2}$ criterion. A significance threshold of $p>0.05$ was set.

\section{RESULTS}

The study included 1563 patients (755 women and 808 men) aged 37 to 59 years (mean age $45.2 \pm 4.6$ years) who underwent rear posterior lumbar fusion.

The incidence of SSIs in the study group was 2.67\% (41). Monomicrobial SSIs were detected in $46.3 \%$ (19) patients, polymicrobial in $36.5 \%$ (15) cases and negative seeding results were verified in $17.07 \%$ (7) patients. At 4.08\% (2) patients, a second hospitalization was required to perform audit interventions on the wound with complex SSI therapy. Gram-positive bacteria were identified in 65.5\% (57) patients with SSIs, gram-negative microorganisms in 29.8\% (26) cases and fungal isolates in in $7.3 \%$ (4) of the patients. The most frequent pathogens of SSIs in the study group were S. aureus and S. epidermidis, with $37.9 \%$ (33) and $24.1 \%$ (21), respectively. Other common etiologic agents of SSls were: Enterococcus spp. - 11.4\% (10), E. coli - 8.04\% (7), Propionibacterium spp. - 5.74\% (5) and Peptostreptococcus $-4.59 \%$ (4). Table 1 shows all the identified SIC agents and their incidence.

The average period of development of symptoms of SSIs in patients after posterior lumbar fusion was $25.9 \pm 65.3$ days. At the same time, when gram-negative pathogens were detected, the period of symptom development of this complication had a shorter duration $21.5 \pm 40.3$ days. The longest period of development of symptoms of SSIs was noted in the case of identification of Propionibacterium spp., which was $35.8 \pm 44.2$ days. (Table 2 )

Methicillin-resistant S. aureus and S. epidermidis (MRSA and MRSE) were verified in $24.1 \%$ (21) cases. It should be noted that the frequency of occurrence of MSSA was almost twice that of MRSA. On the other hand, the prevalence of MRSE was also almost twice the frequency of MSSE. Vancomycin-resistant Enterococcus was isolated in 7.3\% (3) patients with SSIs. Cefazolinresistant gram-negative bacteria accounted for $42.3 \%$ (11) of all the SSIs caused by gram-negative bacteria, and $12.6 \%$ of the total number of microorganisms sown. In $2.29 \%$ (2) cases $E$. coli resistant to cefazolin and producing a wide spectrum of $\beta$-lactamases were sown. 
Table 1. Types of SSls pathogens in patients after posterior lumbar fusion and the frequency of their occurrence.

\begin{tabular}{|c|c|c|}
\hline Microorganism & $\%$ & $\mathbf{N}$ \\
\hline S. aureus & 37.9 & 33 \\
\hline MRSA & 4.59 & 8 \\
\hline MSSA & 9.19 & 16 \\
\hline S. epidermidis & 24.1 & 21 \\
\hline MRSE & 6.89 & 13 \\
\hline MSSE & 3.44 & 7 \\
\hline Enterococcus spp. ${ }^{*}$ & 11.4 & 10 \\
\hline E. coli & 8.04 & 7 \\
\hline Peptostreptococcus & 4.59 & 4 \\
\hline Propionibacterium spp. ** & 5.74 & 5 \\
\hline$P$ aeruginosa & 2.29 & 2 \\
\hline P. mirabilis & 2.29 & 2 \\
\hline A. baumannii & 1.14 & 1 \\
\hline Candida spp. & 1.14 & 1 \\
\hline A. fumigatus & 1.14 & 1 \\
\hline
\end{tabular}

* - vancomycin-resistant E. faecium (3), E. gallinarum (7); ${ }^{* *}$ - P. acnes (4) P. avidum (1).

Table 2. Period of development of symptoms of SSI depending on the type of microorganism.

\begin{tabular}{c|c}
\hline Microorganism & Days to SSI \\
\hline All & $25,9 \pm 65.3$ \\
\hline Gram-negative microorganisms & $21.5 \pm 40.3$ \\
\hline S. aureus & $19.6 \pm 47.1$ \\
\hline S. epidermidis & $24.1 \pm 42.5$ \\
\hline Enterococcus spp. & $23.8 \pm 54.3$ \\
\hline E. coli & $24.7 \pm 38.6$ \\
\hline Peptostreptococcus & $28.1 \pm 39.4$ \\
\hline P. acnes & $35.8 \pm 44.2$ \\
\hline
\end{tabular}

In patients who underwent repeated surgical interventions on the lumbar spine, SSIs was significantly more common, in contrast to the group of patients who were first operated for degenerative disease of the lumbar spine $(p=0.0023)$ (Figure 1). The number of diagnosed cases of SSIs caused by gram-negative bacteria increased with statistical significance from the level of the intervertebral disc L1-L2 to L5-S1 $(p=0.034)$ (Figure 2).

\section{DISCUSSION}

SSIs represent one of the most challenging complications in surgical practice. The present retrospective cohort study presents the results of the analysis of the microbiological characteristics of SSIs cases in patients after posterior lumbar fusion for its degenerative disease. Given the high prevalence of methicillin-resistant strains of the genus Staphylococcus spp. and other microorganisms with multiple drug resistance, a clear understanding of the microbiology

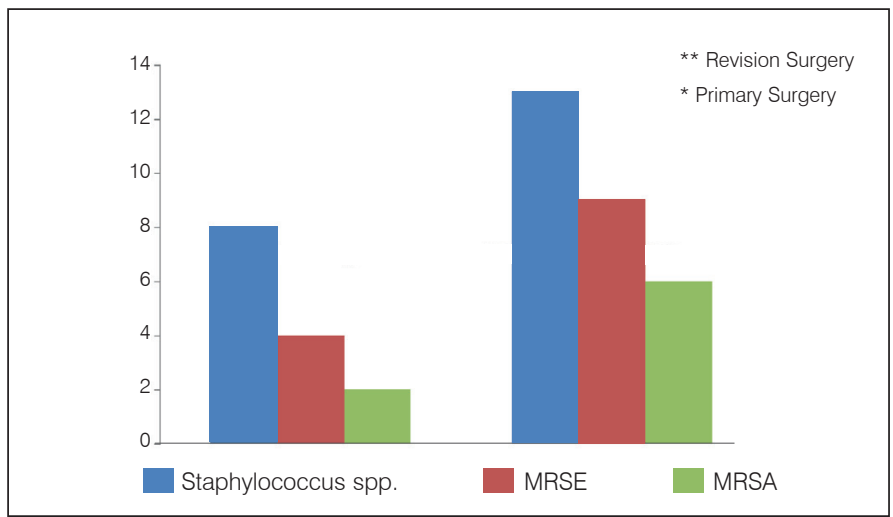

Figure 1. Number of SSls cases caused by Staphylococcus spp. (including MRSE and MRSA) in the groups of patients with first-time and repeated surgical interventions: there is a significant difference in the overall prevalence of SSIs between these groups and the incidence of SSIs caused by MRSA $\left(^{*}-p=0.0023,{ }^{* *}-p=0.0041\right)$.

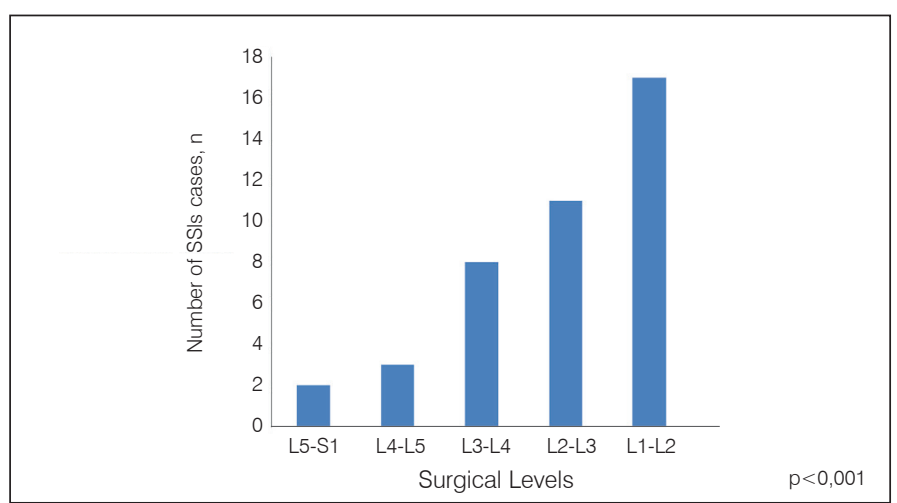

Figure 2. Number of SSls cases after the performed posterior lumbar fusion depending on the operated level.

of SSIs should be developed to modify the perioperative prevention of this type of adverse events and the selection of effective empirical antimicrobial therapy.

In our study, most of the causative agents of SSIs belonged to the gram-positive microflora, mainly $S$. aureus and S. epidermidis. The results obtained are in many ways consistent with data from other clinical and microbiological studies confirming the predominant participation of skin microflora in the role of etiological agents of SSIs. ${ }^{14,19,20}$ It has been proven that S. epidermidis is the most common causative agent of SSIs in patients who have undergone lumbar or lumbosacral fusion, ${ }^{21}$ a fact that was also confirmed by the results of this study. When identifying S. epidermidis from a detachable wound, the tactics of treating a patient with SSIs should be determined by the medical team working in conjunction, consisting of a neurosurgeon, general surgeon, infectious disease specialist and clinical pharmacologist. This is because the genus Staphylococcus spp. is capable of rapid biofilm formation on the surface of implanted implants, which nullifies the effectiveness of antibiotic therapy. ${ }^{22,23}$ The studies that have been conducted on the characteristics of the formation of biofilms (the rate of their formation and resistance to the action of antimicrobial drugs), depending on the material of the implants (stainless steel, titanium, cobalt and chromium alloy) did not show significant differences. ${ }^{24}$

It should be noted that in most cases, SSIs symptoms developed in patients who underwent repeated fusion surgeries on the spine, the causative agents of which were methicillin-resistant Staphylococcus spp. In a study by Abdul-Jabbar et al. ${ }^{25}$ using the binary logistic regression method, it was proven that decompression-stabilizing surgical interventions performed at the 
low lumbar level significantly increased the risk of SSIs. Current clinical recommendations for antibiotic prophylaxis of SSIs do not regulate the widespread use of vancomycin, however, in patients at high risk of developing this complication, the use of vancomycin is considered necessary. ${ }^{26}$ In our opinion, patients who undergo repeated operations on the spine have a high risk of SSIs, and local use of vancomycin powder to prevent this type of complications is an effective and justified method.

The prevalence of SSIs caused by gram-negative microflora was $29.5 \%$, which fully agrees with the data from the global literature. ${ }^{13,27}$, ${ }^{28}$ It is important to note that the majority of cases of SSIs in which the gram-negative bacteria acted as an etiological agent were significantly more frequent at the lower lumbar level, which probably reflects the microbial landscape of the skin in this anatomical region. This is also confirmed by the fact that in the overwhelming majority of cases of SSIs in patients who had undergone surgical interventions at the lower lumbar level, microbial associations are distinguished. Nevertheless, it cannot be unequivocally asserted that the cause of the development of SSIs in this group of patients is intraoperative inoculation of bacteria or postoperative sowing of the wound by the urinary and/ or fecal microflora. Undoubtedly, the data obtained underscore the importance of pre-surgical treatment of the skin (shaving the areas of surgery and douches with antiseptic solutions), and also of swabbing the operating field with alcohol antiseptic solutions, at least three times. ${ }^{29,30}$ In addition, in the postoperative period, special attention should be given to the processing and dressing of wounds, especially in the lower lumbar spine. In a systematic review by Xing et al. ${ }^{31}$ it was shown that prolonged use of active drainage in patients after lower lumbar and lumbosacral fusion significantly increases the risk of SSIs. Undoubtedly, it is necessary to conduct further large multicenter studies to determine the role of the level of the operated segment and active drainage of the wound in the development of SSIs.

The relatively high percentage of cefazolin-resistant gramnegative microflora casts doubt on the efficacy of this antibacterial drug in preventing the development of SSIs. On the other hand, the overall prevalence of cefazolin-resistant gram-negative bacteria among all isolated pathogens is low, and in most cases of SSIs, the causative agent was the genus Staphylococcus spp. Taking into account the accumulated experience of the Neurosurgical Center of the Road Clinical Hospital at st. Irkutsk-Passenger (Irkutsk, Russia) on prevention and treatment of SSIs in patients after various surgical interventions on the spine, we recommend the use of cefazolin in perioperative prevention of this complication, including in patients at high risk. This antibacterial drug has a broad spectrum of action, can be administered intravenously and intramuscularly with a small amount of undesirable drug reactions, and is low in cost.

\section{Limitations of the study}

This study has a number of limitations that need to be identified. It is a retrospective study, which could not but affect the quality of data collection for analysis. In addition, the work was carried out in one institution only, which has certain features of the microbial landscape of the department and the operating unit; this does not allow us to extrapolate the data obtained to other medical and preventive institutions. Undoubtedly, it is necessary to conduct further large-scale studies with the inclusion of several institutions and a larger number of patients under study, which will allow us to reliably estimate and analyze the statistical data obtained.

\section{CONCLUSION}

SSIs in spinal neurosurgery are important prognostic factors for the clinical outcome of surgical treatment of patients, the quality of care provided, and the cost-effectiveness of hospitalization. Modification of modern methods of antibiotic prophylaxis of SSIs in patients after performed surgical interventions on the spine will significantly reduce the incidence of this complication, improve the results of treatment of this group of patients, and reduce the costs of practical health care for the provision of specialized medical care for patients with degenerative diseases of the spinal column. The present study evaluates the microbiological characteristics of SSIs in indissoluble connection with their surgical features. The data obtained by us can be used in the designation of empirical antimicrobial therapy, taking into account the characteristics, the type of operation performed, and the probable pathogen of SSIs, including when choosing rational antibiotic prophylaxis with fewer unwanted drug reactions. Perioperative administration of cefazolin and intraoperative topical application of vancomycin powder is a justified and effective method of antibiotic prophylaxis of SSIs in patients at high risk. Thus, the evaluation of microbiological characteristics should be carried out in all diagnosed cases of SSIs in patients after surgical interventions on the spine, in close connection with the surgical features of the infectious process. The tactics of treatment of this group of patients is determined by a medical team working in conjunction, consisting of a neurosurgeon, general surgeon, infectious disease specialist, clinical pharmacologist and epidemiologist.

All authors declare no potential conflict of interest related to this article.

CONTRIBUTION OF THE AUTHORS: Each author made significant individual contributions to this manuscript. VAB (0000-0003-4349-7101)* were the main contributors in the drafting of the manuscript. IAS (0000-0001-9039-9147)* performed the surgery, followed up patients and gathered clinical data. VEB (0000-0001-5389-929X)* and MDA (0000-0002-5842-5904)* evaluated the data from the statistical analysis. IAS and VAB performed the literature search and review of the manuscript, and contributed to the intellectual concept of the study. *ORCID (Open Researcher and Contributor ID).

\section{REFERENCES}

1. Norman G, Atkinson RA, Smith TA, Rowlands C, Rithalia AD, Crosbie EJ et al. Intracavity lavage and wound irrigation for prevention of surgical site infection. Cochrane Database Syst Rev. 2017;(10):CD012234.

2. Cheng H, Chen BPH, Soleas IM, Ferko NC, Cameron CG, Hinoul P. Prolonged Operative Duration Increases Risk of Surgical Site Infections: A Systematic Review. Surg Infect (Larchmt). 2017;18(6):722-35.

3. Martin ET, Kaye KS, Knott C, Nguyen H, Santarossa M, Evans R et al. Diabetes and Risk of Surgical Site Infection: A Systematic Review and Meta-analysis. Infect Control Hosp Epidemiol. 2016;37(1):88-99.

4. Byvaltsev VA, Stepanov IA, Borisov VE, Kalinin AA, Pleshko IV, Belykh EG et al. Surgical site infections in spinal neurosurgery. Kazan Medical J. 2017;98(5):796-803.

5. Anderson DJ, Podgorny K, Berríos-Torres SI, Bratzler DW, Dellinger EP, Grrene L et al. Strategies to Prevent Surgical Site Infections in Acute Care Hospitals: 2014 Update. Infect Control Hosp Epidemiol. 2014;35(6):605-27.
6. Hyldig N, Birke-Sorensen H, Kruse M, Vinter C, Joergensen JS, Sorensen JA et al. Meta-analysis of negative-pressure wound therapy for closed surgical incisions. $\mathrm{Br} \mathrm{J}$ Surg. 2016;103(5):477-86.

7. Cizik AM, Lee MJ, Martin BI, Bransford RJ, Bellabarba C, Chapman JR et al. Using the spine surgical invasiveness index to identify risk of surgical site infection: a multivariate analysis. $J$ Bone Joint Surg Am. 2012:94(4):335-42.

8. Patel H, Khoury H, Girgenti D, Welner S, Yu H. Burden of Surgical Site Infections Associated with Select Spine Operations and Involvement of Staphylococcus aureus. Surg Infect (Larchmt). 2017;18(4):461-73.

9. Ando M, Tamaki T, Yoshida M, Sasaki S, Toge $Y$, Matsumoto $T$ et al. Surgical site infection in spinal surgery: a comparative study between 2-octyl-cyanoacrylate and staples for wound closure. Eur Spine J. 2014;23(4):854-62.

10. Pull ter Gunne AF, van Laarhoven CJHM, Cohen DB. Incidence of surgical site infection following adult spinal deformity surgery: an analysis of patient risk. Eur Spine J. 2010;19(6):982-8. 
11. Bratzler DW, Dellinger EP, Olsen KM, Perl TM, Auwaeter PG, Bolon MK et al. Clinical practice guidelines for antimicrobial prophylaxis in surgery. Am J Health Syst Pharm. 2013;70(3):195-283.

12. Mangram AJ, Horan TC, Pearson ML, Silver LC, Jarvis WR. Guideline for prevention of surgical site infection, 1999. Hospital Infection Control Practices Advisory Committee. Infect Control Hosp Epidemiol. 1999;20(4):250-78

13. Horwitz NH, Curtin JA. Prophylactic antibiotics and wound infections following laminectomy for lumber disc herniation. J Neurosurg. 1975;43(6):727-31.

14. Kowalski TJ, Berbari EF, Huddleston PM, Steckelberg JM, Mandrekar JN, Osmon DR. The management and outcome of spinal implant infections: contemporary retrospective cohort study. Clin Infect Dis. 2007:44(7):913-20.

15. Rihn JA, Lee JY, Ward WT. Infection after the surgical treatment of adolescent idiopathic scoliosis: evaluation of the diagnosis, treatment, and impact on clinical outcomes. Spine (Phila Pa 1976). 2008;33(3):289-94.

16. Thalgott JS, Cotler HB, Sasso RC, LaRocca H, Gardner V Postoperative infections in spinal implants. Classification and analysis - a multicenter study. Spine (Phila Pa 1976). 1991;16(8):981-4.

17. Schwab F, Gastmeier P. Piening B, Geffers C. The step from a voluntary to a mandatory national nosocomial infection surveillance system: the influence on infection rates and surveillance effect. Antimicrob Resist Infect Control. 2012;1:24.

18. Williams JR. The Declaration of Helsinki and public health. Bull World Health Organ. 2008;86(8):650-2.

19. McClelland $S 3^{\text {rd }}$, Hall WA. Postoperative central nervous system infection: incidence and associated factors in 2111 neurosurgical procedures. Clin Infect Dis. 2007:45(1):55-9.

20. Rao SB, Vasquez G, Harrop J, Maltenfort M, Stein N, Kaliyadan G et al. Risk factors for surgical site infections following spinal fusion procedures: a case-control study. Clin Infect Dis. 2011;53(7):686-92

21. Viola RW, King HA, Adler SM, Wilson CB. Delayed infection after elective spinal instrumentation and fusion. A retrospective analysis of eight cases. Spine (Phila Pa 1976). 1997:22(20):2444-50

22. Dakheel KH, Abdul Rahim R, Neela VK, Al-Obaidi JR, Hun TG, Yusoff K. Methicillin-
Resistant Staphylococcus aureus Biofilms and Their Influence on Bacterial Adhesion and Cohesion. BioMed Research International. 2016;2016:4708425.

23. Yadav MK, Chae SW, Im GJ, Chung JW, Song JJ. Eugenol: A Phyto-Compound Effective against Methicillin-Resistant and Methicillin-Sensitive Staphylococcus aureus Clinical Strain Biofilms. PLoS ONE. 2015;10(3):e0119564.

24. Adachi K, Tsurumoto T, Yonekura A, Nishimura S, Kajiyama S, Hirakata Y et al. New quantitative image analysis of staphylococcal biofilms on the surfaces of nontranslucent metallic biomaterials. J Orthop Sci. 2007:12(2):178-84.

25. Abdul-Jabbar A, Takemoto S, Weber MH, Hu SS, Mummaneni PV, Deviren V et al. Surgical site infection in spinal surgery: description of surgical and patient-based risk factors for postoperative infection using administrative claims data. Spine (Phila Pa 1976). 2012;37(15):1340-5

26. Anderson DJ, Podgorny K, Berríos-Torres S, Bratzler D, Dellinger EP, Grrene L et al. Strategies to Prevent Surgical Site Infections in Acute Care Hospitals:2014 Update. Infect Control Hosp Epidemiol. 2014;35(6):605-27.

27. Rihn JA, Lee JY, Ward WT. Infection after the surgical treatment of adolescent idiopathic scoliosis: evaluation of the diagnosis, treatment, and impact on clinical outcomes. Spine (Phila Pa 1976). 2008:33(3):289-94.

28. Abdul-Jabbar A, Berven SH, Hu SS, Chou D, Mummaneni PV, Takemoto S et al. Surgical site infections in spine surgery: identification of microbiologic and surgical characteristics in 239 cases. Spine (Phila Pa 1976). 2013;38(22):E1425-31.

29. Lee I, Agarwal RK, Lee BY, Fishman NO, Umscheid CA. Systematic review and cost analysis comparing use of chlorhexidine with use of iodine for preoperative skin antisepsis to prevent surgical site infection. Infec Control Hosp Epidemiolo. 2010:31(12):1219-29.

30. Maiwald M, Chan ES. The forgotten role of alcohol: a systematic review and meta-analysis of the clinical efficacy and perceived role of chlorhexidine in skin antisepsis. PLoS One. 2012;7(9):e44277

31. Xing D, Ma JX, Ma XL, Song DH, Wang J, Chen $Y$ et al. A methodological, systematic review of evidence-based independent risk factors for surgical site infections after spinal surgery. Eur Spine J. 2013;22(3):605-15. 